\title{
REKONSTRUKSI METODOLOGI PENGEMBANGAN SAINS BERBASIS AGAMA
}

\author{
Mohammad Muslih \\ Universitas Darussalam Gontor \\ muslih@unida.gontor.ac.id
}

\begin{abstract}
The development of an integrative scientific paradigm is certainly a very large scientific project, however, it must be admitted that the success of reconstructing the new paradigm is still insufficient, as it must be supported by the availability of a functional and effective methodology. This article is a study aimed at offering a methodology for integrative paradigm-based science development, which is not only functional and effective, but also ensures productivity, as well as secure from the pseudo-scientific of abusive practices and the excessive practice of ideological science. The reconstruction of a methodology of religious-based science development urged to do, on the one hand, to provide an answer to the doubt about its compatibility with the Islamic sciences, and on the other hand deny the fear of the disappearance of Islamic values, precisely with the continued execution of scientific research, or the development of scientific reason, in general.
\end{abstract}

Keywords:Paradigm, Hard Core, Auxiliary Hypotheses, Series of Theory

\begin{abstract}
Abstrak
Pembangunan paradigma ilmiah integratif sudah tentu merupakan proyek keilmuan yang sangat besar, meski demikian, harus diakui, keberhasilan melakukan rekonstruksi paradigma baru itu masih belum cukup, sebab masih harus didukung oleh tersedianya metodologi
\end{abstract}


yang fungsional dan efektif. Artikel ini merupakan kajian bermaksud menawarkan metodologi pengembangan sains berbasis paradigma integratif, yang tidak hanya fungsional dan efektif, tetapi juga menjamin produktivitas, sekaligus aman dari jeratan praktek kasar pseudosaintifik dan praktek berlebihan sains ideologis. Rekonstruksi metodologi pengembangan ilmu berbasis agama mendesak untuk dilakukan, di satu sisi untuk memberi jawaban atas keraguan akan kompetabilitasnya dengan ilmu-ilmu keislaman, dan pada sisi yang lain membantah kekhawatiran akan hilangnya atau terkikisnya nilai-nilai keislaman, justru dengan semakin dijalankannya riset-riset ilmiah, atau dikembangkannya nalar ilmiah secara umum.

Kata Kunci: Paradigm, Hard Core, Auxiliary Hypotheses, Series of Theory

\section{A. Pendahuluan}

Ada yang tertinggal dari gegap gempitanya wacana integrasi keilmuan satu atau dua dasawarsa belakangan ini, yaitu penglihatan dari sudut pandang Filsafat Ilmu. Isu integrasi keilmuan nyatanya memang tidak hanya menarik diikuti sebagai suatu wacana keilmuan, tetapi justru lebih tepat dan lebih maju jika dilihat dalam kerangka pembangunan paradigma baru keilmuan (new paradigm). Berdirinya beberapa universitas Islam, negeri dan swasta, setelah melalui proses panjang konversi kelembagaan, seperti UIN, Universitas NU, Universitas Muhammadiyah, UNIDA Gontor, dan lain-lain, merupakan simbol keberhasilan dari proyek besar keilmuan itu. Disebut demikian, karena upaya itu sekaligus menandai lahirnya paradigma ilmiah baru yang mempertemukan sains dan agama, sebagai basis penyelenggaraan tridarma perguruan tinggi, dan khususnya sebagai basis paradigmatik pengembangan keilmuan yang dicanangkannya. Sudah tentu, ini merupakan capaian keilmuan yang cukup gemilang, yang sejarah patut mencatatnya.

Bangunan paradigma ilmiah yang mempertemukan sains dan agama akan mempunyai signifikasi sangat tinggi, jika berujung dengan lahirnya produk keilmuan dengan corak baru yang integratif. Namun nyatanya hingga lebih dari satu dasa warsa ini paradigma keilmuan baru itu belum menunjukkan hasil yang maksimal, untuk tidak dikatakan mandul atau bahkan menguap begitu saja. Persoalan utamanya adalah 
karena belum ada dukungan metodologi yang fungsional, sehingga bukan hanya tidak melahirkan produktivitas keilmuan, tetapi bahkan ditinggalkan oleh komunitas ilmiahnya.

Artikel ini merupakan hasil kajian tentang rekonstruksi metodologi pengembangan ilmu berbasis agama, sebagai semacam alternatif sekaligus dapat mengisi 'kekosongan' metodologi dalam melahirkan produk keilmuan yang berbasis agama, dalam konteks Islam. Terkonstruksinya metodologi yang fungsional dan operasional, akan menjamin produktivitas, sekaligus aman dari jeratan praktek kasar pseudosaintifik dan praktek berlebihan sains ideologis.

\section{B. Memasuki Problem Metodologi}

Dinamika keilmuan PTKI pada umumnya, dan UIN pada khususnya tampaknya terus menjadi sorotan, seiring dengan harapan besar masyarakat, bahkan mungkin harap-harap cemas juga, mengenai apa yang terjadi selanjutnya dengan pertemuan agama dan sains. Sebab nyatanya, proyek besar keilmuan itu memang tidak hanya memiliki kaitan dengan persoalan keilmuan semata, tetapi juga berdampak luas, terutama terkait paham keagamaan masyarakat pada umumnya. Jika selama ini, agama (dengan segala ajarannya) dipahami sebagai berseberangan dengan ilmu, dan begitu selanjutnya, ilmu (dengan segala ciri dan kriterianya) dipahami tidak mungkin bertemu dengan agama, namun paradigma baru itu, mau tidak mau, juga melalukan rekonstruksi untuk ditemukan area pertemuan (negotiation area) bagi keduanya. Dengan begitu, 'bayang-bayang' beragama yang ilmiah, atau harapan ilmu yang agamis, sudah tidak lagi sebagai cita-cita, apalagi sekedar impian, tetapi pelan-pelan dapat diwujudkan.

Dengan sedikit perbedaan, terutama pada aspek simbolik yang merupakan kekuatan sekaligus distingsinya masing-masing, paradigma keilmuan yang dibangun PTKI pada umumnya menempatkan alQur'an sebagai basis pengembangan ilmu. Untuk sekedar menyebut beberapa di antaranya, UIN Jakarta dengan konsep "Reintegrasi Ilmu-ilmu dalam Islam”; UIN Yogyakarta dengan konsep "IntegrasiInterkoneksi” dengan metafora "Spider Web Keilmuan”; UIN Malang 
dengan konsep "Integrasi Ilmu dalam Islam” dengan metafora Pohon Ilmu; UIN Bandung dengan konsep "Wahyu Memandu Ilmu" dengan metafora Roda; UIN Makasar dengan konsep "Integrasi dan Interkoneksi Sains dan Ilmu Agama" dengan metafora Sel Cemara; UIN Pekanbaru dengan konsep "Mengukuhkan Eksistensi Metafisika Ilmu dalam Islam. ${ }^{1}$

Lahirnya paradigma baru ini sudah menjadi sejarah penting dalam perjalanan perguruan tinggi Islam di Indonesia, bahkan perjalanan pemikiran dan keilmuan di Indonesia. Penggunaan metafora yang kemudian menjadi ciri khas paradigma keilmuan masing-masing UIN itu menunjukkan pola pikir, jalan pikiran (logika) atau bangunan nalar, yang sudah tertata sedemikian rupa, yang bagaimanapun rumit dan komprehensipnya cakupan dari bangunan pemikiran itu, tetap dapat dimengerti secara lebih sederhana. Maka metafora itu pada dasarnya merupakan suatu simbol yang menggambarkan keluasan dan kedalaman makna, yang jika dilihat pada wilayah praktis akan sangat kompleks. Maka yang pokok dari paradigma keilmuan adalah mempunyai bangunan nalar dan ada proses panjang pembangunannya sebagai konteksnya, serta untuk membangun konteksnya yang baru, ${ }^{2}$ yang pada saatnya nanti akan menjadi semacam madzhab keilmuan yang punya kekhasan masing-masing: Madzhab Yogya dan Madzhab Malang,. ${ }^{3}$ dan lain-lain.

Dari konteks Filsafat ilmu, suatu pemikiran dapat berkembang menjadi paradigma keilmuan, jika memenuhi setidaknya tiga ciri pokok, yaitu: pertama, ada konvensi dari komunitas ilmiah, ${ }^{4}$ dalam arti didukung oleh sekumpulan komunitas ilmuwan atau researcher;

\footnotetext{
${ }^{1}$ Lihat Nanat Fatah Natsir dan Hendriyanto Attan, (Eds.), Strategi Pendidikan: Upaya Memahami Wahyu dan Ilmu, Cet. 1 (Yogyakarta: Pustaka Pelajar, 2010), h. 1-2

${ }^{2}$ Jika mengikuti al-Jabiry, paradigma keilmuan itu dapat dilihat dari aspek bunyatul 'aql dan takwin al-'Aql.

${ }^{3}$ Bahkan sebutan madzhab sebagai pengembangan konstruksi pemikiran lebih dulu populer. Lihat misalnya karya: Munawar Ahmad dan Saptoni (peny.), Re-Strukturisasi Metodologi Islamic Studies: Mazhab Yogyakarta (Yogyakarta: Suka Press, 2007),

${ }^{4}$ Lihat David Novitz, Picture and their Use in Communication: A Philosophical Essay, (netherlands: The Hague, 1977), h. 77
} 
kedua, pemikiran itu sudah menstruktur dalam kesadaran, sehingga dapat terbangun suatu tradisi dan budaya ilmiah yang khas, ${ }^{5}$ bahkan hingga berbentuk madzhab pemikiran; ketiga, pemikiran itu ditopang dengan lahirnya banyak karya pendukung sebagai auxiliary hypotheses, ${ }^{6}$ yang mengembangkannya pada aspek-aspek keilmuan tertentu, dan membreakdown-nya pada wilayah praktis-aplikatif dalam bentuk metodologi ilmiah dan metode penelitian. Dengan memperhatikan ciri-ciri pokok ini, maka tidak semua pemikiran lantas dapat dianggap sebagai paradigma keilmuan, betapapun canggihnya, akan tetapi yang paling memungkinkan adalah bilamana pemikiran keilmuan itu dikembangkan menjadi bangunan keilmuan (scientific bulding) pada universitas atau lembaga tertentu. Meski demikian, tetap perlu dicatat, bahwa betatapun canggihnya, yang namanya paradigma ilmiah, pada saatnya, pada masanya, akan berproses, sehingga terjadi anomali, lalu krisis, dan berakhir dengan "pergeseran paradigma" (paradigm shifting). Pola demikian tidak bisa ditolak, sebab hanya dengan proses seperti itu ilmu pengetahuan akan mengalami perkembangan.

Sejauh ini, penelitian seputar implementasi paradigma keilmuan UIN sudah banyak dilakukan, di antaranya: a). Nurlena Rifai, implementasi paradigma keilmuan UIN seluruh Indonesia dalam Strktur Kurikulum dan Pola Pembelajaran, ${ }^{7}$ b). Erik Budianto, implementasi paradigma keilmuan UIN Malang, ${ }^{8}$ c). Abdurrahman Assegaf, dkk. implementasi paradigma keilmuan UIN Yogyakarta

${ }^{5}$ Kondisi begini, oleh Thomas S.Kuhn disebut dengan Sains Normal. Lihat Thomas S. Kuhn, The Structure of Scientific Revolutions, (US: University of Chicago Press, 1970), h. 35-42

${ }^{6}$ Bruce J. Caldwell "The Methodology of Scientific Research Programmes: Criticisms and Conjectures", dalam G. K. Shaw ed. (1991) Economics, Culture, and Education: Essays in Honor of Mark Blaug Aldershot, (UK: Elgar, 1991), h. 95-107

${ }^{7}$ Nurlena Rifai, Fauzan, Wahdi Sayuti, Bahrissalim, Integrasi Keilmuan dalam Pengembangan Kurikulum di UIN Se-Indonesia: Evaluasi Penerapan Integrasi Keilmuan UIN dalam Kurikulum dan Proses Pembelajaran, (Jakarta: UIN Syarif Hidayatullah Jakarta, 2014)

${ }^{8}$ Erik Budianto, Implementasi Integrasi Ilmu di Perguruan Tinggi Islam (Studi Kasus di UIN Maulana Malik Ibrahim Malang), (Malang: PPS UIN Malang, 2009) 
pada materi dan bahan ajar, ${ }^{9}$ d). Kuswinarno, implementasi paradigma keilmuan UIN Yogyakarta pada skripsi, e). Prof. Siswanto Masruri, dkk, implementasi paradigma 6 UIN pada karya disertasi, ${ }^{10} \mathrm{~d}$ ). Dr. Waryani, implementasi paradigma UIN Yogyakarta pada 3 karya disertasi. ${ }^{11}$

Beberapa penelitian tersebut menujukkan betapa kajian seputar implementasi paradigma UIN telah menyita perhatian sejumlah peneliti. Hal ini sekaligus juga menandakan adanya harapan besar bahwa bangunan paradigma keilmuan UIN itu bisa benar-benar menjelma menjadi tradisi keilmuan baru yang distingtif. Namun, pada umumnya mereka membuat kesimpulan yang kurang menggembirakan, misalnya disebut bahwa implementasi keilmuan UIN belum maksimal, bahkan ada yang berkesimpulan sedang mencari-cari bentuk. Sudah tentu ini satu persoalan keilmuan yang cukup serius, yang menunjukkan bahwa keberhasilan melakukan rekonstruksi paradigma baru itu ternyata belum cukup, sebab masih harus didukung oleh tersedianya metodologi yang operasional dan fungsional. Maka upaya rekonstruksi metodologi pengembangan ilmu berbasis agama mendesak untuk dilakukan, di satu sisi untuk memberi jawaban atas keraguan akan kompetabilitasnya dengan ilmu-ilmu keislaman, dan pada sisi yang lain membantah kekhawatiran akan hilangnya atau terkikisnya nilainilai keislaman, justru dengan semakin dijalankannya riset-riset ilmiah, atau dikembangkannya nalar ilmiah secara umum. Secara lebih teknis, metodologi pengembangan sains berbasis agama, sangat diperlukan tidak hanya untuk mendorong terjadinya produktivitas keilmuan,

${ }^{9}$ Abdurraman Assegaf dan Muh. Isnanto, "Muatan Keilmuan Integrasi Interkoneksi Dalam Materi Pokok dan Bahan Ajar Matakuliah Keislaman Dosen UIN Sunan Kalijaga Yogyakarta”, Laporan Hasil Penelitian, (Yogyakarta: Lemlit, 2010)

${ }^{10}$ Munawar Ahmad, Lukman Fauroni, Siswanto Masruri, "Rekonstruksi dan Implementasi Metodologi Berparadigma Integrasi-Interkoneksi dalam Studi Islam Kontemporer di Indonesia" (Studi atas Disertasi Doktoral pada 6 UIN), Laporan Penelitian, (Jakarta: Kementerian Agama RI Direktorat Jenderal Pendidikan Islam, 2013).

${ }^{11}$ Waryani Fajar Riyanto, Implementasi Paradigma Integratif-Interkonesi dalam Penelitian 3 (Tiga) Disertasi Dosen UIN Sunan Kalijaga, (Yogyakarta: Lemlit UIN Sunan Kalijaga Yogyakarta, 2012) 
tetapi sekaligus menjamin untuk aman dari jeratan praktek kasar pseudosaintifik ${ }^{12}$ dan praktek berlebihan sains ideologis. ${ }^{13}$

\section{Pengembangan Ilmu dalam Bentuk Program Riset}

Seperti telah disinggung di bagian awal, bahwa rekonstruksi paradigma baru yang integratif masih belum cukup, meskipun itu merupakan proyek keilmuan yang sangat besar, sebab masih harus didukung oleh tersedianya metodologi, agar menjadi fungsional dan bahkan operasional. Namun, harus diakui masih sulit ditemukan metodologi pengembangan ilmu yang memberikan posisi bagi prinsip metafisis dan apalagi prinsip keimanan keagamaan untuk menjadi bagian tak terpisahkan dari bangunan keilmuan.

Adalah Imre Lakatos, filsuf ilmu asal Hungaria (1922-1974), yang menawarkan pola pengembangan ilmu yang disebut "metodologi program riset", di mana di situ ada beberapa kata kunci, yaitu hardcore, auxiliary hypotheses, dan series of theories, sebagai semacam 'lapis-lapis' konseptual bagi pengembangan ilmu, yang tidak saja memberikan ruang bagi tradisi dan budaya ilmiah (di samping teori dan metodologi yang memang tidak bisa ditawar-tawar), tetapi juga tersedia posisi "asumsi tak terbantahkan", yang berada pada lapis terdalam pada scientific building. Asumsi tak terbantahkan ini tidak lain semacam prinsip-prinsip dan nilai-nilai keyakinan, termasuk keyakinan keagamaan. Metodologi Program Riset merupakan pemikiran orisinil Lakatos. Gagasan ini muncul untuk mengembangkan sebuah pemikiran alternatif agar terjamin akan terjadinya kemajuan dalam teori-teori ilmiah. Menurut Lakatos, persoalan pokok terkait logika penemuan

${ }^{12}$ Pseudosains merupakan isu khas filsafat ilmu, terutama sejak perbincangan tentang patokan ilmiah atau kriteria ilmiah menjadi begitu sentral dalam kajian filsafat ilmu, dimulai oleh Positivisme Logis, lalu menjadi semakin tegas di Karl Popper dan Imre Lakatos. Lihat Stanford Encyclopedia of Philosophy, dalam http://plato.stanford. edu/entries/pseudo-science/ diakses Jum'at, 07 Okt 2016 jam 03.45

${ }^{13}$ Istilah ini diadaptasi dari Kuntowijoyo dalam gagasannya tentang objektivikasi Islam, dari mitologi, lalu ideologi menuju ilmu, yang di sini digunakan untuk menyebut aktivitas dan karya ilmiah yang dibangun untuk menegaskan identitas diri sekaligus menandingi identitas yang lain, bangsa lain, misalnya sains Barat. Lihat Kuntowijoyo, Islam Sebagai Ilmu, h. 80-81 
(logic of discovery) baru akan berhasil diselesaikan jika dikerjakan dalam kerangka metodologi program riset. ${ }^{14}$

Dalam program riset ini terdapat aturan metodologis yang disebut dengan heuristic, ${ }^{15}$ yaitu semacam metode pemecahan masalah melalui penalaran, pengalaman, dan percobaan-percobaan, sekaligus menghindar- kan dari kesalahan dalam menyelesaikan masalah. Apa yang disebut sejarah ilmu pengetahuan pada dasarnya adalah sejarah program riset, lebih dari sekedar soal perkembangan teori. Suatu program riset, menurut Lakatos, mengandung tiga elemen, yaitu hard core, protective belt, dan series of theories.

Pertama, 'Inti Pokok' (Hard Core), yaitu "asumsi dasar” yang melandasi program riset ilmiah, sekaligus menjadi ciri pokoknya, yang posisinya tidak dapat ditolak atau dimodifikasi, serta harus dilindungi dari ancaman falsifikasi. Dengan posisinya seperti itu, 'Hard Core' disebut sebagai heuristik negatif, yaitu bahwa inti yang solid dari asumsi fundamental yang sudah semestinya tidak sampai dibatalkan. Dalam suatu program riset, heuristik negatif itu merupakan tuntutan, bahwa selama program masih dalam perkembangan, inti-pokoknya tetap utuh, tetap tidak dimodifikasi, sebab ia menjadi dasar di atas elemen yang lain. Konsekuensinya, jika seorang ilmuwan maksa mengadakan modifikasi terhadap asumsi fundamental itu, maka sebenarnya ia telah memilih keluar dari program riset yang dilakukan. ${ }^{16}$

Kedua, 'Lingkaran Pelindung' (Protective Belt), yang terdiri dari beberapa hipotesa bantu (auxiliary hypotheses). Dalam aturan metodologis Program Riset, Auxiliary Hypotheses itu perposisi sebagai heuristik positif, satu aspek dari program riset yang memungkinkan

${ }^{14}$ Arthur Zucker, Introduction to the Philosophy of Science (New Jersey: Prentice-Hall Inc, 1996), h. 167-168.

${ }^{15}$ Menurut kamus filsafat, Heuristics is the study of methods and discovery, A heuristic is a procedure for achieving a result which does not consist simply in applying certain general rules which are guaranteed to lead to the result in question. Lihat A.R. Lacey, A Dictionary of Philosophy (London, New York: Routledge, 2000), h. 131.

${ }^{16}$ Lakatos, "Falsification and the Methodology of Scientific Research Programmes”, dalam Imre Lakatos dan Alan Musgrave (ed.) Criticism and the Growth of Knowledge, (Cambridge: Cambridge University Press, 1974)., h. 135-136. 
ilmuwan membuat modifikasi dan penyesuaian-penyesuaian terhadap program risetnya. Heuristik positif menunjukkan bagaimana inti-pokok program harus dilengkapi agar dapat menerangkan dan meramalkan fenomena yang nyata. Dalam kata-kata Lakatos sendiri, "Heuristik positif terdiri sebagian dari perangkat isyarat tentang bagaimana mengubah, mengembangkan varian-varian yang dapat dibantah dari suatu program riset, bagaimana memodifikasi dan meningkatkan lingkaran pelindung yang dapat diperdebatkan itu". ${ }^{17}$ Ada dua hal yang ditolak oleh metodologi Lakatos, yaitu: hipotesa-hipotesa ad hoc, hipotesa yang tidak dapat diuji secara independent. Misalnya adalah tidak ilmiah untuk mengemukakan bahwa gerak planet Uranus yang kacau itu karena memang demikianlah gerak alaminya. Cara lain yang ditolak adalah metode kerja yang "memperkosa inti-pokok program", sebab bila hal ini dilakukan, maka dinamika keilmuan akan semakin surut ke belakang. ${ }^{18}$

Ketiga, 'Serangkaian Teori' (a series of theories), yaitu keterkaitan teori, yang mana teori berikutnya merupakan akibat dari klausul bantu yang ditambahkan dari teori sebelumnya. Karena itu, bagi Lakatos, yang harus dinilai sebagai ilmiah atau tidak ilmiah bukanlah teori tunggal, melainkan rangkaian beberapa teori. Yang terpenting dari serangkaian perkembangan ilmu dan rangkaian teori adalah ditandai oleh kontinuitas yang pasti. Suatu program riset dapat dinilai ilmiah, jika memenuhi dua syarat, yaitu: pertama, telah memenuhi tingkat koherensi yang tinggi dengan ukuran mengandung perencanaan yang mapan untuk program riset selanjutnya; kedua, telah dapat menghasilkan penemuan berupa fakta baru. ${ }^{19}$ Elemen Program Riset yang ketiga ini, sudah tentu, meniscayakan adanya kesinambungan antara satu teori yang akan dikembangkan dengan teori sebelumnya yang sudah dianggap establish.

17 Ibid.

html

${ }^{18} \mathrm{Http}$ ///www.personalityresearch.org/metatheory/lakatos/hueristics.

${ }^{19}$ Lakatos, "Falsification and the Methodology", h. 135-136 
Kemajuan atau kemunduran program riset dapat dibuktikan dari dua sudut pandang, yaitu dari perspektif teoritik dan perspektif empirik. Oleh sebab itu, rivalitas antar teori itu dapat terjadi secara tidak terelakkan sebagai konsekuensi logis dari kebutuhan kemajuan. Namun ada hal yang perlu digarisbawahi, bahwa salah satu kesulitan dalam kriteria menerima atau menolak suatu program riset berkaitan dengan waktu. Berapa waktu diperlukan sebelum suatu program dapat ditentukan sudah mengalami kemerosotan secara serius? Karena masih tidak menentu bagaimana hasil suatu usaha di masa depan untuk mengembangkan atau menguji suatu program, maka tidak pernah bisa dikatakan apakah program itu telah mengalami degenerasi dan sudah tidak mempunyai harapan apa-apa lagi. Mengutip jawaban Lakatos sendiri; "Our answer, in outline, is that such an objective reason is provided by a rival research programme which explains the previous success of its rival and supersedes it by a further display of heuristic power" ${ }^{20}$

Dari kerangka kerjanya, konsep Lakatos ini jelas posisinya di hadapan Popper adalah menindaklanjutinya. Falsifikasi ia kritik, tetapi kemudian ia mengembangkannya menjadi falsifikasi yang sofistikitit. Inilah yang kemudian disebut sebagai suatu bentuk "metatheory", sekaligus inilah yang menjadi kekuatan pemikirannya. Tulisan Lakatos tentang "Popper on Demarcation and Induction"22 merupakan kritik tentang klaim penganut falsifikasionis yang menyatakan telah memecahkan persoalan induksi. Lakatos berarti telah mendudukkan kembali falsifikasi dengan cara yang lebih canggih dengan keberhasilannya merumuskan cara kerja program riset.

\section{${ }^{20}$ Ibid., h. 140.}

${ }^{21}$ Istilah ini sudah berkembang luas dan mempunyai pengertian yang banyak. Dalam diskursus filsafat ilmu, metateori dimaknai sebagai suatu teori yang tidak hanya sekedar mampu menjelaskan fakta, akan tetapi juga mampu meramalkan fenomena ke depan. Namun secara sederhana dapat pula dipahami sebagai "methods of evaluating theories", lihat Http://www.personalityresearch.org/metatheory.html Diakses Senin 02 Agustus 2016 jam 22.00

${ }^{22}$ Artikel Lakatos ini dimuat dalam P.A. Schilpp (ed.), The Philosophy of Karl R. Popper, (La Salle, Illionis: Open Court, 1974). 


\section{Relevansi Program Riset dalam Pengembangan Ilmu-Ilmu}

\section{KeIslaman}

Dalam sejarah Filsafat Ilmu, dengan mengikuti "jejak" perkembangan ilmu alam, Auguste Comte menunjukkan keberhasilannya membidani kelahiran sosiologi modern, yang sekaligus mengantarkannya disebut sebagai Bapak Sosiologi Modern. ${ }^{23}$ Kontribusi Comte di bidang ini terkait refleksi filosofisnya tentang metodologi ilmiah, di samping tentang data positif sebagai ukuran ilmiah dan lahirnya teori yang tak terbantahkan sebagai kriteria pengembangan ilmu. ${ }^{24}$ Upaya Auguste Comte ini pada akhirnya membawa kepada diskusi tentang apakah masih diperlukan pembedaan antara ilmu alam dan ilmu sosial, sementara kriteria ilmiah dan metodologi ilmiah sudah begitu jelas.

Wilhelm Dilthey berpandangan, bahwa antara dua bidang keilmuan itu terdapat perbedaan prinsip, yang secara metodologis tidak mungkin bisa disatukan, yaitu metode erklaren untuk ilmuilmu kealaman, dan metode verstehen untuk ilmu-ilmu sosial. ${ }^{25}$ Berbeda dengan Dilthey, kelompok Vienna Circle ${ }^{26}$ berpandangan, bagaimanapun kerja ilmiah harus menggunakan metodologi dan bahasa ilmiah yang sama, sehingga tidak signifikan membedakan jenis ilmu, seperti ilmu alam dan ilmu sosial. ${ }^{27}$

Antara ilmu-ilmu kealaman dan ilmu-ilmu sosial, sudah tentu terdapat keunikan tersendiri yang tidak dapat begitu saja saling ditukarkan, namun juga tidak dapat dinafikan jika terdapat 'norma

${ }^{23}$ Zainuddin Maliki, Narasi Agung: Tiga Teori Sosial Hegemonik, (Surabaya: LPAM, 2003), h. 39.

${ }^{24}$ Antony Flew, A Dictionary of Phylosophy, (New York: St. Martin’s Press, 1984), h. 283

${ }^{25}$ Richard E. Palmer,Hermeneutics: Interpretation Theory in Schleiermacher, Dilthey, Heidegger, and Gadamer, (London: Evanston, 1969), h. 25

${ }^{26}$ Adalah sekelompok filsuf empiris, ilmuwan, dan matematikawan di Wina dari tahun 1920 sampai tahun 1938, termasuk Rudolf Carnap dan Kurt Gödel. Upaya pokok mereka adalah meletakkan dasar-dasar dari pemikiran positivisme logis.

${ }^{27}$ Thomas Uebel,. 'Vienna Circle', dalam Robert Audi,(ed.), Cambridge Dictionary of Philosophy, (Cambridge:: Cambridge University Press, . 1995), h. 836- 839. 
dan patokan' umum yang berlaku pada jenis keilmuan apapun, bahkan termasuk ilmu-ilmu humanities. 'Norma dan patokan' umum itu pada dasarnya merupakan basis filosofis di balik kerja ilmiah, sebagaimana diletakkan dasar-dasarnya oleh ahli logika dan para filsuf ilmu, termasuk Auguste Comte, kelompok Vienna Circle, Karl R. Popper, Thomas S. Kuhn, dan Imre Lakatos, terutama terkait kriteria ilmiah dan perkembangan ilmu.

Auguste Comte dengan filsafat Positivismenya telah tercatat dalam sejarah sebagai membawa metodologi ilmu alam kepada ilmu sosial (yang awalnya disebut fisika sosial), sementara kelompok Vienna Circle dengan Neo Positivismenya, Karl R. Popper dengan Falsifikasinya, Thomas S. Kuhn dengan Paradigmanya, hingga Imre Lakatos dengan Metodologi Program Risetnya; semuanya mengkostruk pemikiran filsafat ilmu dari refleksinya terhadap sejarah dan perkembangan ilmu alam. Namun demikian, dalam perjalanannya, pemikiran para filsuf ilmu itu terbukti berpengaruh, menginspirasi, dan memiliki relevansi yang cukup signifikan untuk pengembangan ilmu sosial, dan bahkan ilmu-ilmu keislaman. Istilah "hukum positif" adalah contoh paling konkrit dari pengaruh positivisme di bidang ilmu hukum, ${ }^{28}$ bahkan dominasi pemikiran positivisme cukup terasa hingga kini di bidang ilmu-ilmu yang lain. Praktik pengembangan ilmu melalui uji teori, atau kritik ilmiah pada umumnya, bagaimanapun merupakan bentuk paling nyata dari pemikiran Falsifikasi Popper, yang mana model demikian sudah cukup berkembang di bidang ilmu sosial dan keislaman, ${ }^{29}$ setelah model "Konfirmasi” dan "Verifikasi” dinilai kurang berbobot secara ilmiah.

Paradigma, suatu konsepsi yang digagas Thomas Kuhn, juga dibangun berdasarkan kajiannya terhadap perkembangan ilmu alam. Meski demikian Paradigma Kuhn nyatanya berdampak luas terhadap hampir semua jenis ilmu, dalam arti pengembangan

${ }^{28}$ Biyanto, "Positivisme dan Non-Positivisme dalam Jurisprudensi", Teosofi: Jurnal Tasawuf dan Pemikiran Islam, Volume 3 Nomor 2 Desember 2013, pp. 483-502

${ }^{29}$ Menarik untuk dicermati, satu artikel yang ditulis Komaruddin, "Falsifikasi Karl Popper dan Kemungkinan Penerapannya dalam Keilmuan Islam” at-Taqaddum, Volume 6, Nomor 2, Nopember 2014. 
ilmu pada jenis ilmu apapun, pada dasarnya tidak dapat keluar dari kerangka paradigmanya. Heddy Shri Ahimsa-Putra adalah salah satu ilmuwan yang begitu gencar menawarkan pengembangan Antropologi Budaya dalam kerangka paradigma. ${ }^{30}$ Pengaruh Kuhn pada bidang keilmuan sosial budaya juga terlihat pada paradigma profetik yang dikembangkan oleh Kuntowijoyo. ${ }^{31}$ Gagasan paradigma profetik ini juga banyak mendapat penjelasan dari Heddy Shri, sehingga tidak saja menjadi lebih mudah dimengerti, tetapi juga dapat menjadi lebih fungsional dan bahkan oprasional, sebagai kerangka pengembangan ilmu sosial, yang kemudian disebut dengan ilmu sosial profetik. Paradigma profetik, dicirikan, tidak hanya mengandung perangkat nilai pengembangan ilmu yang bersifat akademik, yang sekedar dijalankan untuk memahami dan menjelaskan berbagai gejala dalam kehidupan manusia, tetapi juga terdapat "etos" yang menjadi basis pengembangan ilmu yang bersifat transformatif, baik transformasi individu, keluarga, maupun masyarakat dalam rangka menghasilkan perubahan dalam kehidupan kemasyarakatan dan kebudayaan. ${ }^{32}$

Nama Imre Lakatos memang tidak sepopuler Thomas S. Kuhn, lebih-lebih bagi akademisi Islamic Studies. Meski demikian bukan tidak mungkin Lakatos mengikuti jejak Kuhn yang pemikirannya terus bergulir, dikembangkan, tidak hanya dalam bidang ilmu sosial, tetapi juga ilmu-ilmu keislaman. "Konsep" paradigma yang digagas Kuhn sudah sedemikian mapan pada hampir semua bidang ilmu, dan lebih dari itu, paradigma Kuhn menyadarkan bahwa di balik teori

${ }^{30}$ Dalam pandangan Heddy Shri, unsur-unsur pokok sebuah paradigma ilmu sosial-budaya adalah: (1) Asumsi-asumsi dasar; (2) Model-model; (3) Konsepkonsep; (4) Metode-metode penelitian; (5) Meto-de-metode analisis; dan (6) Hasil-hasil analisis. Bisa juga ditambahkan di sini (7) masalah-masalah yang ingin diselesaikan, dijawab, atau pertanya-an-pertanyaan. Lihat Heddy Shri Ahimsa-Putra, "Paradigma, Epistemologi dan Metode Ilmu Sosial-Budaya - Sebuah Pemetaan -" Makalah disampaikan dalam pelatihan "Metodologi Penelitian", diselenggarakan oleh CRCS-UGM, di Yogyakarta, 12 Februari - 19 Maret 2007, h. 7-8

${ }^{31}$ Kuntowijoyo, Islam sebagai Ilmu: Epistemologi, Metodologi dan Etika, (Yogyakarta: Tiara Wacana, 2006)

${ }^{32}$ Heddy Shri Ahimsa-Putra, "Paradigma Profetik, Mungkinkah? Perlukah?”, Makalah disampaikan dalam "Sarasehan Profetik 2011", diselenggarakan oleh Sekolah Pascasarjana UGM, di Yogyakarta, 10 Februari 2011 
dan metodologi sebagai aspek logis dari ilmu, masih ada paradigma sebagai aspek historis, dan sosio-antropologis dari ilmu. Artinya, jika pada ilmu alam saja terdapat unsur historisitas dan sosio-antropologis, sudah tentu paling tidak hal yang sama juga terjadi pada ilmu sosial dan ilmu keislaman.

Proyek "kritik nalar" oleh para pemikir Islam kontemporer, sudah tentu dapat dibaca sebagai upaya penelusuran atau pembongkaran terhadap aspek historis dan sosio-antropologis di balik paham keagamaan dan keilmuan Islam. ${ }^{33}$ Selain itu tidak dapat disembunyikan adanya kegelisahan terkait paradigma ilmu-ilmu keislaman, terhadap kemungkinan adanya anomali, krisis, dan bahkan revolusi, sehingga perlu dibangun paradigma baru. ${ }^{34} \mathrm{M}$. Amin Abdullah adalah satu di antara tokoh yang melihat bahwa ilmu-ilmu keislaman sudah waktunya mengalami pergeseran paradigma. ${ }^{35}$ Terkonstruknya paradigma integrasi-interkoneksi UIN Yogyakarta adalah jawaban atas kegelisahan akademiknya selama ini, sekaligus merupakan kontribusinya yang paling nyata terhadap dunia keilmuan, dan lebih khusus lagi, ilmu-ilmu keislaman.

Dengan bangunan paradigma integrasi interkoneksi, Amin Abdullah bukan hanya menunjukkan relevansi pemikiran Lakatos terhadap pengembangan ilmu-ilmu keislaman, tetapi bahkan telah memposisikannya sebagai dasar atau pola dasar dari bangunan paradigma itu. ${ }^{36}$ Lebih jauh dari itu, di tangan Amin Abdullah, pemikiran Lakatos berhasil direkonstruksi menjadi jauh lebih komprehensif, tidak saja karena beberapa konsep kunci mendapatkan penjelasan yang baru, tetapi juga membuat jangkauan spektrumnya

${ }^{33}$ M. Amin Abdullah, "Aspek Epistemologis Filsafat Islam”, dalam Irma Fatimah (ed.), Filsafat Islam, (Yogyakarta: LESFI, 1992), h. 39.

${ }^{34}$ Pervez Hoodbhoy, Ikhtiar Menegakkan Rasionalitas: Antara Sains dan Ortodoksi Islam, (Terj. Sari Meutia), (Bandung: Mizan, 1996), h. 204

${ }^{35}$ M. Amin Abdullah, Studi Agama, Normativitas atau Historisitas, (Yogyakarta: Pustaka Pelajar, 1996), h. 103.

${ }^{36}$ Waryani Fajar Riyanto, "Pengembangan Kurikulum Ilmu-Ilmu Keislaman di PTAI (Sebuah Ikhtiar Pencarian Landasan Filosofi)”, Forum Tarbiyah, Vol. 11, No. 2, Desember 2013, h. 159 
menjadi semakin luas sampai kepada keilmuan Islam, dan yang lebih penting lagi, pengembangan ilmu-ilmu keislaman kemudian mendapatkan dukungan basis filosofisnya secara lebih kokoh dalam bentuk paradigma baru itu.

Oleh karena itu, dari perspektif filsafat ilmu, persoalan digunakannya dasar filosofis pengembangan ilmu alam untuk pengembangan ilmu sosial dan humaniora, diskusinya bukan lagi mungkin apa tidak mungkin, sebab saling share basis filosofis bahkan detail metodologi sudah terjadi sepanjang sejarah ilmu. Ilmu sosiologi bisa jadi menggunakan metodologi ilmu alam untuk menjelaskan fakta sosial, tetapi sosiologi ilmu, tidak dapat disangkal, adalah memanfaatkan metodologi dan logika sosiologi untuk membaca perkembangan ilmu-ilmu, bahkan termasuk ilmu alam. Demikian juga, ilmu sejarah dengan sejarah ilmu, ilmu antropologi dengan antropologi ilmu, bisa dikatakan, sudah saling bertukar metodologi. Sementara terkait penggunaan konsep Lakatos untuk pengembangan ilmu-ilmu keislaman, dan lebih khusus lagi yang dikembangkan UIN, adalah bukan hal baru, apalagi mengada-ada, sebab itu sudah menjadi bagian terpenting dari bangunan paradigmanya. ${ }^{37}$ Meskipun dalam beberapa hal masih perlu dikembangkan, terutama pada aspek praktis operasionalnya. Pertanyaan, mengapa harus Lakatos, memang bukanlah pertanyaan pokok, sebabnya pada kenyataannya pola pengembangan ilmu pada jenis ilmu apapun tidak bisa menghindar dari sorotan filsafat ilmu, dan harus diakui pemikiran filsafat ilmu yang memiliki tingkat kompetabilitas dengan ilmu berbasis agama adalah konsep yang ditawarkan Lakatos. Sudah tentu, ini baru benar-benar dapat dijalankan setelah terlebih dulu ada penyesuaian-penyesuaian dan beberapa modifikasi. ${ }^{38}$

${ }^{37}$ Waryani Fajar Riyanto, Integrasi-Interkoneksi Keilmuan: Biografi Intelektual M. Amin Abdullah (1953-... ), Person, Knowledge, and Institution, (Yogyakarta: Suka Press, 2013), h. 1171-1178

${ }^{38}$ Dalam catatan Waryani, Amin Abdullah sudah memperkenalkan pemikiran Imre Lakatos di kalangan mahasiswa untuk kemudian dilakukan modifikasi sejak tahun 1995, sehingga di tahun 2002 metafora "spider web" mulai dipublikasikan. Lihat Ibid. 
Dalam program pengembangan ilmu, baik terkait ilmu alam, ilmu sosial humaniora, maupun ilmu keislaman, tidak dapat dinafikan keberadaan "asumsi dasar" yang dalam taraf tertentu bersifat "tidak terbantahkan". Meskipun pada kenyataannya asumsi dasar itu dapat bersumber dari teori-teori besar (grand theory), sementara pada ilmu yang berbasis agama, seperti ilmu keislaman, dan nanti sains Islam, asumsi dasar itu merupakan asumsi teologis yang bersumber dari norma atau doktrin agama. Sudah tentu perbedaan sumber ini dapat saja melahirkan asumsi yang berbeda, akan tetapi tetap terbuka kemungkinan terjadi kesamaan, termasuk maksud dan bahasa yang sama pula. Terkait persoalan ini, sumbangan dari diskusi filsafat ilmu bukanlah soal apa asumsi yang mendasari setiap rumpun ilmu, tetapi lebih kepada soal, bahwa pengembangan ilmu tidak dapat mengabaikan apa yang menjadi asumsi dasarnya. Meskipun di sisi lain, filsafat ilmu juga tidak tinggal diam untuk terus melakukan kritisisme terhadap apa yang dijadikan asumsi dasar dari pengembangan ilmu.

Di dalam pemahaman keislaman, dan terutama dalam ilmu-ilmu keislaman, secara epistemologis terdapat dua wilayah keislaman yang mesti terus ditemukan posisi dan pola dialektika antar keduanya, yaitu yang umumnya disebut wilayah ushul dan wilayah furu', atau dalam khazanah 'klasik' dikenal sebagai naqli dan aqli. Dua wilayah ini terkait ajaran pokok yang punya nilai tetap (al-tsawabit), dan pemahaman yang bernilai berkembang atau bahkan berubah (al-mutaghayyirat). Dalam perkembangannya, problem ini terus menjadi perhatian ulama, intelektual, dan ilmuwan muslim. Kalangan muslim modernis, seperti Fazlur Rahman mengembangkan konsep Islam normatif dan Islam historis, Nurcholis Madjid memperkenalkannya dengan Islam doktrin dan peradaban, sementara Amin Abdullah mengembangkan "Studi Agama, Normativitas Historisitas”. Dengan konsepsi masing-masing, para pemikir muslim modernis melihat pembedaan dua wilayah itu adalah suatu keharusan agama untuk menghindari sikap pengagamaan pemahaman agama, juga keharusan logika untuk menghindari kerancuan berpikir, dan bahkan keharusan sosial untuk meminimalisir terjadinya resistensi dan perpecahan pada masyarakat mengiringi 
kesalahan memahami agama dan kerancuan berpikir. Konsep turats wa tajdid dari kalangan pemikir muslim kontemporer, juga menunjukkan bahwa problem ini bukan hanya perlu diperhatikan dalam memahami Islam apalagi memproduksi pengetahuan Islam, namun juga perlu dibaca dengan model pembacaan kontemporer.

Kritisisme filsafat ilmu terkait problem epistemologis dengan berbagai konsepsi di atas, sudah tentu tidak hanya menguji keberadaannya, ataupun posisinya, namun juga mempertanyakan fungsi dan kebermaknaan masing-masing, dalam kerangka pengembangan ilmu. Paradigma integrasi interkoneksi yang digagas Amin Abdullah adalah rekonstruksi filsafat keilmuan atas aspek normativitas dan historitas dalam Islam, dengan mempertimbangkan posisi, fungsi, dan dialektika di antara keduanya, bahkan dialektika keduanya dengan problem kontemporer. Dengan mengikuti hard core Imre Lakatos, maka aspek normativitas yang bersifat "tak terbantahkan" itu merupakan wilayah yang mesti terlindung dari upaya refutasi dan falsifikasi, dan pada saat yang sama menjadi "sumber penggerak" bagi pengembangan ilmu pada wilayah historisitas atau series of theory dalam konsepsi Lakatos. Sebagaimana konsep Lakatos, sisi normativitas itu dilingkari sabuk pengaman (protective belt) yang berupa pemikiran bantu (auxiliary hypotheses) yang dalam paradigma integrasi interkoneksi berujud metodologi dan pendekatan, sebelum akhirnya benar-benar dikembangkan pada ragam keilmuan.

Selain beberapa konsep kunci tersebut, ada sejumlah karakter pengembangan ilmu model Lakatos yang dimungkinkan memiliki kompatibilitas dengan pengembangan ilmu keislaman, dan lebih khusus lagi ilmu keislaman berparadigma integratif, yaitu pertama bahwa ukuran keberhasilan proyek pengembangan ilmu itu adalah ditemukannya teori baru dan atau fakta baru, seiring dengan semangat memecah teka teki ilmiah yang disebut dengan heuristik. Beberapa hal ini sudah tentu menuntut adanya program kreatif dengan tingkat produktifitas tinggi. Sudah tentu ini menjamin ilmu keislaman dapat mengalami perkembangan mengejar ketertinggalan dibanding dengan rumpun keilmuan yang lain; kedua, posisi hard core, di samping sebagai 
basis, juga sebagai penggerak yang memungkinkan ilmu bekerja tidak keluar dari kerangka hard core-nya. Maka pengembangan ilmuilmu keislaman, meskipun pada wilayah teori dan metodologi, ilmu bekerja dengan logika ilmiah tingkat tinggi, namun tetap memiliki ciri khas keislaman yang dapat ditelusuri pada basis normativitasnya. ${ }^{39}$ Lebih dari itu, kerja saintifik tidak dimaksudkan untuk menjustifikasi, mengkonfirmasi, apalagi menfalsifikasi basis normativitas- nya, karena secara logika, hal demikian memang tidak sah.

Ketiga, program pengembangan ilmu, pada wilayah teori dan metodologi dapat saling sharing, yang memungkinkan pengembangan ilmu berlangsung secara interdisipliner dan multidisipliner. Pola demikian mensyaratkan ilmu-ilmu keislaman untuk terus mengokohkan diri sebagai ilmu sehingga berada sejajar dengan ilmuilmu pada umumnya, dan pada saat yang sama akan semakin berkurang pola pengembangan ilmu yang bersifat ideologis, lebih-lebih yang bersifat mitologis. Keempat, riset pengembangan ilmu dijalankan dengan berbasis program, yaitu program riset, yang dijalankan secara berkelanjutan melalui riset jangka panjang, dengan skema yang rasional dan roadmap yang realistis. Di sini, poin yang dapat dicatat, bahwa pengembangan ilmu-ilmu keislaman sangat dimungkinkan dijalankan secara lebih bertanggungjawab, melalui program terpadu dalam suatu lembaga riset yang berbasis lembaga keislaman.

Beberapa karakter pengembangan ilmu model Lakatos ini di satu sisi kiranya cukup menjadi jawaban atas keraguan akan kompatibilitasnya dengan ilmu-ilmu keislaman, dan pada sisi yang lain juga membantah kekhawatiran akan hilangnya atau terkikisnya nilainilai keislaman dengan semakin dijalankannya riset-riset ilmiah, atau dikembangkannya nalar ilmiah secara umum.

${ }^{39}$ Bersatupadunya beberapa aspek itu, dalam konteks yang lebih luas, terutama terkait budaya, termasuk terkait kesulitan nalar agama diurainkan panjang lebar oleh Prof. Amin Abdullah dalam kuliah inagurasi pengukuhan dirinya sebagai Anggota Komisi Kebudayaan pada Akademi Ilmu Pengetahuan Indonesia (AIPI) yang bertema: "Agama, Ilmu dan Budaya: Paradigma Integrasi-Interkoneksi" di UGM Selasa, 3 September 2013 


\section{E. Riset Pengembangan Ilmu Berbasis Program}

Seperti diuraikan sebelumnya bahwa pengembangan ilmu berparadigma integratif diandaikan berbentuk riset pengembangan yang berbasis program, dalam arti program riset, secara berkelanjutan, jangka panjang, melalui skema yang rasional dan roadmap yang realistis. Untuk maksud itu lapis-lapis konseptual-metodologis mesti bisa terpilah secara tegas, mana wilayah teoretis-metodologis, mana wilayah paradigma, dan mana wilayah asumsi "tak terbantahkan" yang di sini disebut basis teologis-metafisis.

\section{Pokok-Pokok Ajaran Agama sebagai "Hard Core"}

Paradigma keilmuan integratif pada umumnya menempatkan sumber ajaran Islam, yaitu al-Qur'an dan al-Sunnah sebagai sumber ilmu, atau di sini lebih disebut sebagai basis pengembangan ilmu. Pada UIN Malang misalnya, pengembangan ilmu dapat langsung di-akar-kan pada ayat al-Qur'an, atau ayat al-Qur'an dapat diturunkan dalam bentuk pengembangan ilmu. Berbeda dengan itu, pada UIN Yogyakarta basis agama yang berujud al-Qur'an dan al-Sunnah itu, mengembangkannya ke ranah pengembangan ilmu harus melalui 'pintu masuk' metodologi dan pendekatan (methodology and approach). Ini artinya sebelum sumber ajaran Islam itu dikembangkan menjadi aktivitas ilmiah atau dijadikan inspirasi pengembangan ilmu, terlebih dulu dibangun pemikiran normatif-teologis. Basis keagamaan baik yang bersifat normatif-teologis maupun yang bersifat normatif-tekstual berupa ayat al-Qur'an, dalam perspektif filsafat ilmu Lakatosian, dapat menempati posisi sebagai hardcore atau metateori ${ }^{40}$ yang berada jauh di belakang teori, dalam program pengembangan ilmu. Dalam konsepsi Lakatosian, posisi basis keagamaan dalam program pengembangan ilmu bukan hanya mungkin, tetapi mendapatkan dukungan metodologisnya.

${ }^{40}$ Dalam diskursus filsafat ilmu, metateori dimaknai sebagai suatu teori yang tidak hanya sekedar mampu menjelaskan fakta, akan tetapi juga mampu meramalkan fenomena ke depan. Namun secara sederhana dapat pula dipahami sebagai "methods of evaluating theories", lihat Http://www.personalityresearch.org/metatheory.html diakses pada Sabtu, 06 Agustus 2016 jam 20.55 
Dalam konsepsi "metodologi program riset", proyek pengembangan ilmu itu disebut sebagai heuristic, ${ }^{41}$ yaitu suatu keharusan metodologis untuk mendatangkan penemuan-penemuan ilmiah dengan melakukan usaha pemecahan masalah ilmiah lewat penalaran, pengalaman, serta lewat percobaan-percobaan, sekaligus menghindarkan dari kesalahan dalam menyelesaikan masalah. Secara metodologis, kerangka kerja (conceptual framework) heuristik itu terdiri dari hard core (inti pokok) yang berposisi sebagai "heuristik negatif" (negativeheuristic) ${ }^{42}$ dan auxiliary hypotheses (hipotesis bantu) yang berposisi sebagai "heuristik positif" (positive heuristic). ${ }^{43}$

Dalam kerangka "metodologi program riset", basis keagamaan itu berposisi sebagai hard core, yaitu asumsi dasar yang menggerakkan, yang membuat aktivitas ilmiah itu terjadi meskipun berbasis agama. Melihat posisinya itu, maka keberadaan basis keagamaan tidak akan tersentuh oleh upaya "Falsifikasi" dan "Refutasi", sebab jangkauan keduanya hanya pada wilayah teori. Selain itu, hard core juga dikelilingi oleh auxiliary hypotheses yang berfungsi sebagai "Sabuk Pelindung" (protective belt) yang membuat hard core berada pada posisi aman. Dengan demikian, maka pengembangan ilmu model Lakatosian ini kondisinya berbeda jauh dengan model Bucaillean yang menjustifikasi temuan teoretis dengan teks keagamaan. Sebagai konsekuensinya jika temuan teoretis terjatuh dan gugur dengan falsifikasi dan refutasi oleh temuan yang lebih kuat, maka teks keagamaan yang dijadikan pembenaran juga ikut terjatuh dan gugur. Di sini, pernyataan Holmes Rolston III, bisa dimengerti: "The religion that is married to science

${ }^{41}$ Lihat A.R. Lacey, A Dictionary, h. 131

${ }^{42}$ Disebut heuristik negatif, karena kepadanya tidak tersedia jalan bagi upaya penyalahan (falsifikasi) atau penyangkalan (refutasi). Lebih jauh lihat pernyataan Lakatos: The negative heuristic forbids scientists to question or criticize the hard core of a research programme. The positive heuristic consists of a partially articulated set of suggestions or hints on how to change, develop the 'refutable variants' of the research programme, how to modify, sophisticate, the 'refutable' protective belt. Lakatos, Musgrave ed., Criticism and the Growth of Knowledge, (Cambridge: Cambridge University Press, 1970), h. 135

${ }^{43}$ Heuristik positif mengandaikan kemungkinan adanya perubahan, ataupun menerima masukan. 
today will be a widow tomorrow". ${ }^{44} \mathrm{Hal}$ ini tidak akan terjadi pada proyek pengembangan ilmu model metodologi program riset Lakatosian, sebab agama dan sains, menjaga keotonomian integritas dan ketahanan masing-masing. ${ }^{45}$

Pada saat yang sama, dengan menempatkan basis keagamaan pada posisi hardcore, maka pengembangan ilmu pada wilayah tradisi dan budaya ilmiah dengan segala aspeknya, dan pada wilayah teori dengan segala kerangka kerja dan metodologinya, akan dapat 'bekerja' pada posisinya masing-masing, bukan campur aduk, antara teori dengan ayat al-Qur'an misalnya. Dengan kerangka pikir seperti ini, maka pengembangan ilmu pada wilayah teori (atau dengan basis teori) akan berjalan atau dijalankan dengan tingkat logika penemuan (logic of discovery) yang tinggi. Demikian juga pengembangan ilmu pada wilayah tradisi dan budaya ilmiah dalam bentuknya sebagai madzhab keilmuan, bukan hanya dapat mengakomodir sisi sosiologis, historis, dan antropologis dari bangunan paradigma keilmuan, tetapi bahkan kerja ilmiah itu benar-benar berjalan di atas madzhab keilmuan itu. Pengembagan ilmu dengan kerangka kerja demikian, akan tetap berada dalam kerangka agama, namun juga tidak mengurangi kadar keilmiahannya, atau sebaliknya meski tetap bekerja dengan tingkat keilmiahan yang tinggi, tetapi tidak keluar dari kerangka agama, bahkan dengan kesadaran kerangka agama. Dengan kata lain, dalam perspektif ini, pengembangan ilmu bukan hanya merupakan aktivitas kemanusiaan (dengan segala kompleksitasnya), tetapi sekaligus juga sebagai aktivitas keagamaan (dengan berbagai nalar keagamaannya), namun tetap merupakan aktivitas ilmiah yang rasional dan faktual, yang dapat diuji secara metodologis dan teoretis.

Pada sisi yang lain, proyek pengembangan ilmu seperti itu akan segera dapat menjawab persoalan pseudosaintifik yang selalu dialamatkan kepada keilmuan yang berbasis agama, sebagai ilmu palsu,

${ }^{44}$ Holmes Rolston, III, Science and Religion: A Critical Survey, (New York: Random House, Inc., 1987), h. vii

${ }^{45}$ Dalam hal ini, Holmes Rolston menyatakan: "It needs to keep its autonomous integrity and resilience." Lihat ibid. 
semu, dan tidak ilmiah. Sebab nyatanya memang pada posisi yang menjunjung tinggi standard ilmiah, meskipun 'pada posisinya' tidak akan pernah menafikan adanya kesadaran 'intersubjektifitas' tradisi dan budaya ilmiah, dan bahkan juga 'pada posisinya' berada dalam kerangka agama. Sudah tentu upaya membasiskan pengembangan ilmu ke agama ini bukan soal 'kepuasan' ilmiah, tetapi soal tanggung jawab ilmiah, juga bukan soal merespon tantangan ilmu sekuler, tetapi soal menawarkan kemanfaatan yang seluas-luasnya bagi keilmuan, sosial, dan kemanusiaan. Dengan begitu, pengembangan ilmu berbasis agama itu juga bukan proyek ideologis, tetapi proyek ilmiah yang bernilai agama.

Dengan maksud seperti itu, maka dalam proyek pengembangan ilmu dengan basis al-Quran dan al-Sunnah, mesti dengan penuh tanggungjawab dan sangat otoritatif, bukan dengan cara mengambil hanya satu ayat lalu dikembangkan menjadi kegiatan ilmiah, juga bukan dengan cara menjustifikasi teori sebagai temuan dari kerja ilmiahnya dengan ayat al-Quran. Melainkan dengan mempertemukan beberapa ayat yang berkaitan, sehingga lahir pemahaman yang komprehensif, yang dari pemahaman itu dapat ditentukan proyek pengembangan ilmu jangka panjang. Sudah tentu, upaya menemukan pemahaman yang komprehensif itu tidak bisa tidak mesti melibatkan expert yang otoritatif di bidang kajian al-Quran.

\section{Hipotesis Bantu dan Rentetan Teori; Tradisi Akademik dan Eksemplar Program}

Dalam proyek pengembangan ilmu, sudah tentu kokohnya tradisi dan budaya ilmiah dalam bentuk tradisi akademik adalah elemen yang juga sangat penting. Ciri khas dan bentuk 'intersubyektifitas' komunitas ilmiah dalam satu madzhab ilmiah, tidak mungkin lagi ditutup-tutupi atau disembunyikan, demi obyektiftas. Maka pengembangan ilmu model "metodologi program riset" ini, sudah melewati era positivistik yang mensyaratkan steril dari unsur subyektifitas individu ilmuwan apalagi intersubyektifitas tradisi ilmiah. Lebih jauh lagi, model "metodologi program riset" ini, juga telah melampaui pandangan neopositivisme yang mengeliminasi 'nalar' 
metafisika, etika, estetika, ${ }^{46}$ dan lebih-lebih nalar agama sebagai hanya masuk "unscientific discourse", sebab bahasa yang digunakan hanyalah "pseudostatements" yang bersifat meaningless ${ }^{47}$ atas dasar tidak mungkinnya dapat diverifikasi secara faktual dan dengan data positif.

Dalam satu tradisi ilmiah, komunitas ilmiah dapat menyumbangkan pemikiran-pemikiran tambahan sebagai "auxiliary hypotheses", di satu sisi untuk menopang gagasan 'inti pokok', dan untuk menerjemahkan gagasan 'inti pokok' dalam bentuk-bentuk program penelitian berkelanjutan, di sisi yang lain. Meskipun demikian, apa yang dimaksud dengan pemikiran-pemikiran tambahan itu tidak harus dengan menyebut secara eksplisit paradigma keilmuan yang akan dikembangkannya. Sebab paradigma keilmuan itu dalam aplikasinya memang bukan untuk disebut, apalagi kalau hanya sekedar disebut, tetapi untuk digunakan, dan pada taraf tertentu dapat mewarnai jalan pemikiran, termasuk gaya bahasa yang digunakan. Lain halnya dengan teori, dalam pengembangan ilmu, atau lebih konkritnya, dalam aktivitas ilmiah, keberadaan teori kecuali memang harus digunakan, tetapi juga perlu disebutkan secara eksplisit. Sementara paradigma keilmuan itu memang lebih soft dari pada teori. ${ }^{48}$

Sejalan dengan semakin tertatanya tradisi akademik suatu universitas, yang bisa disimbolkan dengan Smart University, maka pengembangan tridharma perguruan tinggi pada umumnya, dan khususnya di sini, program pengembangan ilmu, tentu saja sudah harus lebih terprogram, dalam arti bukan hanya dengan pencanangan

${ }^{46}$ Editors of Encyclopædia Britannica, "Verifiability principle", Encyclopcedia Britannica, dalam https://www.britannica.com/topic/verifiability-principle, diakses pada Ahad 07 Agustus 2016 jam 08.38

${ }^{47}$ Alyssa Ney, "Neo-Positivist Metaphysics”, Philosophical Studies, August 2012, Volume 160, Issue 1, h. 53-78

${ }^{48}$ Bandingkan dengan pandangan Heddy Shri Ahimsa-Putra yang menyatakan bahwa dari unsur-unsur paradigma, dalam suatu program penelitian, ada yang harus ekplisit dan ada yang tidak harus eksplisit. Lihat Heddy Shri Ahimsa-Putra, "Paradigma dan Revolusi Ilmu dalam Antropologi Budaya -Sketsa Beberapa Episode-", Pidato Pengukuhan Jabatan Guru Besar pada Fakultas Ilmu Budaya Universitas Gadjah Mada, diucapkan di depan Rapat Terbuka Majelis Guru Besar Universitas Gadjah Mada Yogyakarta, 10 November 2008, h. 8-9 
rencana jangka pendek, jangka menengah, dan jangka panjang, tetapi sekaligus ada kejelasan mengenai pengembangan "serangkaian teori" tertentu yang menjadi fokus penelitiannya. Beberapa hal itu, dalam perspektif "metodologi program riset" disebut sebagai rentetan teori (series of theories) yang berupa program riset berkelanjutan dalam rangka merespon dan memecahkan masalah-masalah ilmiah jangka panjang. Maka seperti disinggung di atas, keilmiahan suatu program riset akan dinilai berdasarkan dua syarat: 1). harus memenuhi derajat koherensi; 2) harus dapat menghasilkan penemuan fenomena baru. Berdasarkan dua syarat itu, suatu program riset akan dinilai berhasil jika menunjukkan peningkatan secara progresif baik secara teoritis maupun secara empiris, dan sebaliknya suatu program riset dapat dinilai gagal jika mengalami kemerosotan (degenerative). ${ }^{49}$

Pengembangan keilmuan, baik dalam bidang Islamic Studies maupun bidang Saintek dan Sosial Humaniora, sudah tentu akan jauh lebih dapat dinikmati oleh masyarakat, jika didesain sedemikian rupa dalam bentuk grand project (al-masyru' al-kabir) keilmuan untuk jangka waktu tertentu. Dengan begitu, proyek pengembangan ilmu akan semakin terlihat sebagai proyek institusi dengan agenda terpadu yang jelas, bukan sebagai peroyek pribadi-pribadi atau kelompok-kelompok kecil dosen, yang bagaimanapun belum terlihat menyatupadunya satu sama lain. Dalam catatan Prof. Akh. Minhaji, karena tidak mempunyai agenda terpadu, pengalaman di sejumlah PTAI menunjukkan bahwa kegiatan penelitian seringkali berjalan sendiri-sendiri, malah tumpang tindih, dan hanya berorientasi pada kum. ${ }^{50}$

Dengan tidak bermaksud masuk ke wilayah manajemen PT, namun perhatian kepada lembaga penelitian universitas tampaknya masih perlu untuk terus ditingkatkan. Dalam catatan Prof. Akh. Minhaji, setidaknya ada empat hal yang mesti diperhatikan untuk

${ }^{49}$ Imre Lakatos, Criticism and the Growth of Knowledge, (New York: Cambridge University Press, 1970), h. 91-195; Lihat juga Theodore Schick, Jr., ed., Readings in the Philosophy of Science, (Mountain View, CA: Mayfield Publishing Company, 2000), h. 20-23.

${ }^{50}$ Lihat Akh, Minhaji, Tradisi Akademik di Perguruan Tinggi, (Yogyakarta: SUKA Press, 2013), h. 174 
memberdayakan lembaga penelitian universitas. Pertama, adanya komitmen yang kuat dari para peneliti, dengan terus memiliki ideide kreatif yang layak "jual" dalam bentuk program penelitian; kedua, lembaga penelitian mengusung isu-isu kekinian yang dibutuhkan masyarakat, mengkaitkan program penelitian dengan isu-isu kontemporer; ketiga, lembaga penelitian melibatkan peneliti muda, bahkan peneliti pemula yang dengan semangat tinggi ikut terjun melakukan penelitian; keempat,penguasaan bahasa asing dan kemampuan menggunakan komputer, ${ }^{51}$ termasuk kemampuan akses literatur berbasis online (termasuk e-book, e-journal, dll). Selanjutnya untuk meningkatkan produktivitas penelitian, secara internal terkait tugas dan fungsinya, lembaga penelitian perlu melakukan beberapa program strategis, yaitu: koordinasi penelitian (research coordination), sosialisasi hasil penelitian (socialization), pelatihan (training), penerbitan (publication), jaringan (networking), pembangunan image (image building), dan komitmen moral (moral commitment). ${ }^{52}$

Jika kerangka berpikir ini diterima, maka terdapat tiga wilayah dalam proyek pengembangan ilmu, yaitu wilayah hard core, wilayah auxiliary hypotheses, dan wilayah series of theories. Wilayah pertama yaitu wilayah hard core, yang dalam hal ini merupakan wilayah kajian al-Qur'an dan al-Sunnah, sebagaimana dalam paradigma keilmuan integratif. Maka semestinya, tidak menyentuh wilayah ini kecuali para ahli di bidang sumber ajaran Islam itu, atau sebut saja, ini wilayah kerja ilmuwan Islamic Studies. Produk dari kerja mereka adalah lahirnya konsep-konsep "embrional" yang pada saatnya dikembangkan menjadi program penelitian berkelanjutan untuk jangka waktu tertentu. Wilayah kedua adalah wilayah auxiliary hypotheses, di sini aktivitas yang mungkin dilakukan adalah mempertimbangkan bidang-bidang ilmu yang tercakup di dalam konsep emberional itu, membuat pertimbangan tentang kemungkinan metodologi yang bisa digunakan, dan yang juga penting adalah tetap mempertimbangkan tradisi dan budaya ilmiah dengan memberikan sentuhan 'cita rasa'

\footnotetext{
${ }^{51}$ Lihat Ibid., h. 172-173

${ }^{52}$ Ibid., h. 174
} 
madzhab keilmuannya. Wilayah ini yang kemungkinan membedakan satu madzhab dengan madzhab lainnya, meskipun umpamanya menggunakan metodologi yang sama dan tentang permasalahan yang sama pula. Sedangkan wilayah ketiga adalah wilayah series of theories, wilayah ini merupakan basis terluar dari program pengembangan ilmu. Wilayah ini merupakan wilayah kerja ilmuwan dan peneliti, yaitu mengembangkan, menverifikasi, mengkritik, menguji, menfalsifikasi teori. Dalam kerja ilmiahnya, ilmuwan mesti bertindak secara profesional, berlaku di atas standar dan etika ilmiah. Meskipun mereka tetap tidak hilang kesadaran bahwa mereka berada dalam lingkungan tradisi dan budaya ilmiah dengan madzhab yang mereka ikuti, bahkan bahwa mereka sedang memegangi prinsip keimanan-keagamaan yang mereka yakini.

Meskipun dimungkinkan ada ilmuwan dengan bidang keahlian tertentu dapat melakukan penelitian mengembangkan keilmuannya, yang tidak hanya berada pada wilayah teori (atau dalam hal ini series of theories), namun dengan kemampuannya masuk ke wilayah auxiliary hypotheses, bahkan ke wilayah hard core, namun tetap tidak bisa digolongkan dalam kerangka "metodologi program riset" yang mengandaikan kerja kolektif, sistemik, dan kultural. Dan, untuk saat ini, hampir mustahil (dan tidak perlu), proyek penelitian dilakukan atas nama sendiri, dalam arti tidak dalam kerangka lembaga, termasuk di dalamnya, LSM (lembaga swadaya masyarakat). Berdirinya Wahid Institut yang dinisbatkan ke Gus Dur (alm.), juga Ma'arif Institut yang dinisbatkan ke Buya Syafi'i Ma'arif, dan lain-lain, adalah sekedar contoh NGO yang bergerak di bidang keilmuan, di samping keislaman dan kemasyarakatan. Dalam kerangka pikir ini, sangat boleh jadi, lembagalembaga itu mengembangkan corak keilmuan, sekaligus pola penelitian yang khas, yang berbeda satu sama lain.

\section{F. Penutup}

Bangunan paradigma keilmuan yang mempertemukan sains dan agama akan mempunyai signifikasi yang sangat tinggi jika berujung dengan lahirnya produk keilmuan dengan corak baru yang integratif. 
Namun untuk maksud itu, keberadaan paradigma keilmuan masih harus dibantu dengan adanya dukungan metodologi yang fungsional dan efektif, sehingga tidak hanya melahirkan produktivitas keilmuan, tetapi sekaligus mejamin aman dari proses "pragmatis" mengagamaagamakan sains atau mensains-sainskan agama.

Rekonstruksi metodologi dengan model "metodologi program riset" membukakan pintu bagi proyek pengembangan ilmu berbais agama menjadi lebih terstruktur, dalam budaya ilmiah yang berciri khas, namun tetap mengandaikan adanya lembaga penelitian yang sehat, terdapat program-program kreatif, mempunyai agenda penelitian yang terpadu, dan berjangka panjang. Lebih dari itu, model "metodologi program riset" ini dapat sekaligus menjawab beberapa persoalan yang selama ini membuat program penelitian selalu "gamang" terkait persoalan posisi "agama" yang mesti diintegrasikan dengan aktivitas saintifik; saintifik tapi religius, religius yang sekaligus saintifik. Bahkan lebih jauh lagi, dengan jelasnya tiga lapis wilayah kerja sains sebagaimana diuraikan di atas, lalu menjadi jelas pula, setidaknya secara konseptual, tentang 'kelahiran' sains baru, yaitu sains yang berbasis agama, atau sains yang menyatupadu dengan agama. Lahirnya Sains berbasis Islam itu menjadi mungkin, tidak lain, karena tiga aspek dari ajaran Islam yang, baik secara logis maupun secara keyakinan, memang tidak terpisah, yaitu Islam sebagai agama, Islam sebagai tradisi dan budaya, dan Islam sebagai ilmu. Dengan demikian, proyek pengembangan sains berbasis Islam bukanlah proyek ideologis (yang dipaksakan ada, dan dipaksakan diterima sebagai identitas untuk membedakan diri dengan ideologi 'pesaing'), tetapi benar-benar merupakan proyek saintifik, yang sekalipun berbasis agama namun tidak kurang nilai saintifiknya, dan sekalipun saintifik namun malah semakin tinggi tingkat keislaman-religiusitasnya. [ ] 


\section{DAFTAR PUSTAKA}

\section{Sumber Buku dan Artikel}

Abdullah, M. Amin, "Aspek Epistemologis Filsafat Islam”, dalam Irma Fatimah (ed.), Filsafat Islam, Yogyakarta: LESFI, 1992.

, Studi Agama, Normativitas atau Historisitas, Yogyakarta: Pustaka Pelajar, 1996.

, "Agama, Ilmu dan Budaya: Paradigma Integrasi-Interkoneksi" Pidato pengukuhan sebagai Anggota Komisi Kebudayaan pada Akademi Ilmu Pengetahuan Indonesia (AIPI) yang bertema: di UGM Selasa, 3 September 2013

Ahimsa-Putra, Heddy Shri, "Paradigma, Epistemologi dan Metode Ilmu Sosial-Budaya - Sebuah Pemetaan -" Makalah disampaikan dalam pelatihan "Metodologi Penelitian", diselenggarakan oleh CRCS-UGM, di Yogyakarta, 12 Februari - 19 Maret 2007.

, "Paradigma dan Revolusi Ilmu dalam Antropologi Budaya -Sketsa Beberapa Episode-”, Pidato Pengukuhan Jabatan Guru Besar pada Fakultas Ilmu Budaya Universitas Gadjah Mada, diucapkan di depan Rapat Terbuka Majelis Guru Besar Universitas Gadjah Mada Yogyakarta, 10 November 2008.

, “Paradigma Profetik, Mungkinkah? Perlukah?”, Makalah disampaikan dalam "Sarasehan Profetik 2011", diselenggarakan oleh Sekolah Pascasarjana UGM, di Yogyakarta, 10 Februari 2011

Ahmad, Munawar dan Saptoni (peny.), Re-Strukturisasi Metodologi Islamic Studies: Mazhab Yogyakarta, Yogyakarta: Suka Press, 2007.

Ahmad, Munawar, Lukman Fauroni, Siswanto Masruri, "Rekonstruksi dan Implementasi Metodologi Berparadigma IntegrasiInterkoneksi dalam Studi Islam Kontemporer di Indonesia” (Studi atas Disertasi Doktoral pada 6 UIN), Laporan Penelitian, 
Jakarta: Kementerian Agama RI Direktorat Jenderal Pendidikan Islam, 2013.

Assegaf, Abdurraman, dan Muh. Isnanto, "Muatan Keilmuan Integrasi Interkoneksi Dalam Materi Pokok dan Bahan Ajar Matakuliah Keislaman Dosen UIN Sunan Kalijaga Yogyakarta”, Laporan Hasil Penelitian, Yogyakarta: Lemlit, 2010.

Biyanto, "Positivisme dan Non-Positivisme dalam Jurisprudensi", Teosofi: Jurnal Tasawuf dan Pemikiran Islam, Volume 3 Nomor 2 Desember 2013, pp. 483-502

Budianto, Erik, Implementasi Integrasi Ilmu di Perguruan Tinggi Islam (Studi Kasus di UIN Maulana Malik Ibrahim Malang), Malang: PPS UIN Malang, 2009.

Caldwell, Bruce J., "The Methodology of Scientific Research Programmes: Criticisms and Conjectures", dalam G. K. Shaw ed., Economics, Culture, and Education: Essays in Honor of Mark Blaug Aldershot, UK: Elgar, 1991.

Flew, Antony, A Dictionary of Phylosophy, New York: St. Martin's Press, 1984.

Hoodbhoy, Pervez, Ikhtiar Menegakkan Rasionalitas: Antara Sains dan Ortodoksi Islam, (Terj. Sari Meutia), Bandung: Mizan, 1996.

Komaruddin, "Falsifikasi Karl Popper dan Kemungkinan Penerapannya dalam Keilmuan Islam” at-Taqaddum, Volume 6, Nomor 2, Nopember 2014.

Kuhn, Thomas S., The Structure of Scientific Revolutions, US: University of Chicago Press, 1970

Kuntowijoyo, Islam sebagai Ilmu: Epistemologi, Metodologi dan Etika, Yogyakarta: Tiara Wacana, 2006

Lacey, A.R., A Dictionary of Philosophy, London, New York: Routledge, 2000.

Lakatos, Imre, Criticism and the Growth of Knowledge, New York: Cambridge University Press, 1970. 
, "Falsification and the Methodology of Scientific Research Programmes", dalam Imre Lakatos dan Alan Musgrave (ed.) Criticism and the Growth of Knowledge, Cambridge: Cambridge University Press, 1974.

, Musgrave ed., Criticism and the Growth of Knowledge, Cambridge: Cambridge University Press, 1970.

Maliki, Zainuddin, Narasi Agung: Tiga Teori Sosial Hegemonik, Surabaya: LPAM, 2003.

Minhaji, Akh, Tradisi Akademik di Perguruan Tinggi, Yogyakarta: SUKA Press, 2013.

Natsir, Nanat Fatah dan Hendriyanto Attan, (Eds.), Strategi Pendidikan: Upaya Memahami Wahyu dan Ilmu, Cet. 1, Yogyakarta: Pustaka Pelajar, 2010

Ney, Alyssa, "Neo-Positivist Metaphysics", Philosophical Studies, August 2012, Volume 160, Issue 1

Novitz, David, Picture and their Use in Communication: A Philosophical Essay, Netherlands: the Hague, 1977.

Palmer, Richard E.,Hermeneutics: Interpretation Theory in Schleiermacher, Dilthey, Heidegger, and Gadamer, London: Evanston, 1969.

Rifai, Nurlena, Fauzan, Wahdi Sayuti, Bahrissalim, Integrasi Keilmuan dalam Pengembangan Kurikulum di UIN Se-Indonesia: Evaluasi Penerapan Integrasi Keilmuan UIN dalam Kurikulum dan Proses Pembelajaran, Jakarta: UIN Syarif Hidayatullah Jakarta, 2014.

Riyanto, Waryani Fajar, "Pengembangan Kurikulum Ilmu-Ilmu Keislaman di PTAI (Sebuah Ikhtiar Pencarian Landasan Filosofi)", Forum Tarbiyah, Vol. 11, No. 2, Desember 2013. , Implementasi Paradigma Integratif-Interkonesi dalam Penelitian

3 (Tiga) Disertasi Dosen UIN Sunan Kalijaga, Yogyakarta: Lemlit UIN Sunan Kalijaga Yogyakarta, 2012.

, Integrasi-Interkoneksi Keilmuan: Biografi Intelektual $M$. Amin Abdullah (1953-...), Person, Knowledge, and Institution, Yogyakarta: Suka Press, 2013. 
Rolston, Holmes, III, Science and Religion: A Critical Survey, New York: Random House, Inc., 1987.

Schick, Theodore, Jr., ed., Readings in the Philosophy of Science, Mountain View, CA: Mayfield Publishing Company, 2000.

Schilpp, P.A. (ed.), The Philosophy of Karl R. Popper, La Salle, Illionis: Open Court, 1974.

Uebel, Thomas, 'Vienna Circle', dalam Robert Audi,(ed.), Cambridge Dictionary of Philosophy, Cambridge:: Cambridge University Press, 1995.

Zucker, Arthur, Introduction to the Philosophy of Science, New Jersey: Prentice-Hall Inc, 1996.

\section{Sumber Internet}

Editors of Encyclopædia Britannica, "Verifiability principle", Encyclopredia Britannica, dalam https://www.britannica.com/ topic/verifiability-principle, diakses pada Ahad 07 Agustus 2016 jam 08.38

Http://www.personalityresearch.org/metatheory.html, diakses pada Sabtu, 06 Agustus 2016 jam 20.55

Http://www.personalityresearch.org/metatheory.html, diakses Senin 02 Agustus 2016 jam 22.00

Http://www.personalityresearch.org/metatheory/lakatos/hueristics. html

Stanford Encyclopedia of Philosophy, dalam http://plato.stanford.edu/ entries/pseudo-science/ diakses Jum’at, 07 Okt 2016 jam 03.45 
